\title{
The Sense of Loss in David Rabe's Sticks and Bones
}

\author{
By
}

\author{
Wafaa Hamdy Sorour \\ Lecturer, English Department \\ Qena Faculty of Arts
}

South Valley University 


\section{Abstract:}

This paper explores the sense of loss as reflected in David Rabe's Sticks and Bones at three levels: individual, familial and societal ones. Throughout the play, Rabe successfully captures the lost individual who fails to locate a definite meaning for his/her life and how this failure extends to invade the familial and social lives as well. On the individual level, David, the main character of the play, faces endless suffering after returning blind from the Vietnam War. $\mathrm{He}$ is lost and searches for his own identity. On the familial and societal levels, all the members of David's family, a microcosm of the American society as a whole, vote (even the mother) for getting rid of their returned blind son. Instead of helping him via rehabilitating him, they help him to commit suicide. This paper, therefore, adopts a psychoanalytic approach to examine closely how the sense of loss dominates the whole atmosphere of Rabe's Sticks and Bones. 
The Psychological/psychoanalytical approach in literary criticism views literary works through the lens of Psychology. It tries to identify what is going on inside the human mind and, then, applies psychological theories when interpreting literature. In other words, the psychoanalytical approach views literary text as a revelation of its author's mind and personality and its literary characters as a reflection of the writer. Again, it focuses on the hidden motivation of the literary characters. This approach is based on the theories of many famous experts like Sigmund Freud (1846-1939) and Carl Jung (1875-1961).

Being one of Freud's disciples, Carl Jung, an active member of the Vienna Psychoanalytic Society, adopts and supports the belief that great literature truthfully reflects life. Thus, psychological criticism enables the critic to study 'the interior life' of the writer, and then to study his works. This results in a better understanding and more exact interpretation of the writer and his art.

In this regard, it is important to have a bird's eye view of Jung's terms: "individual and collective unconsciousness" and "archetypes". In A Glossary of Literary Terms, M. H. Abrams demonstrates how Jung does not emphasize the individual unconsciousness; rather, he underscores the significance of the collective unconsciousness. This is mainly due to the fact that it is shared by all individuals in all cultures, which [Jung] calls archetypes (12). Abrams adds that Jung regards great literature "an expression of the archetypes of the collective unconsciousness". A great author possesses, and provides for leaders, access to the archetypal images buried in the racial memory of all the members of the human family" (12-13).

In this context, it is very fruitful to uncover the ambiguous and confusing nature of the Jungian term 'archetype'. In 'The Archetypal School', Michael Adams shows that such ambiguity and confusion stem basically from Jung's multiple definitions of the term 'archetype'. Adams shows how the word 'archetype' is defined, in some cases, as 'images'. In another context, Jung makes a clear distinction between two interchangeable terms: 'archetypes' and 'archetypal images'. While the former refers to those "unconscious forms devoid of any specific content," the latter encompasses "the 'conscious' contents of these forms" (qtd in Adams 107). However, Adams indicates that the word 'archetype' marks "an abstract theme," and the term 'archetypal images' includes those "Concrete variations on that theme" (108). 
Consequently, under the category of 'archetypal images', several classifications can be made. Among them, as mentioned by Abrams, are "narrative designs, patterns of action, character-types, themes and images" (12). The significance of these archetypal images is mainly derived from the fact that they are universal ones. Their universality makes the audience/readers of a work of art find strong echoes of these recurrent items in their own minds (Adams, passim). In other words, both the dramatist and the audience share this heritage of 'archetypal images'. Consequently, this gives birth to a variety of readings for the same work of art.

In the light of Jung's 'archetypes', Rabe's Sticks and Bones came to be a reanimation to this technique of 'archetypes'. While depicting the American soldiers and civilians during and after the Vietnam War, Rabe shows his audience many archetypes of psychological and physical suffering and loss. Besides, the same archetypes of suffering and loss can be found at the levels of the American family and, as a microcosm, at the American society as whole.

To make this point clearer, a connection should be made between Jung and Rabe via shedding light on the nature of the word 'sense'. In his Psychological Types, Jung shows that the word 'sensation' embraces both the external and internal motivations. For him, "sensation is related not only to external stimuli but to kind of inner ones" (461). Undoubtedly, Jung's view of sensation and its external and internal motivations cope with Rabe's view in capturing the external and internal feeling of loss and suffering of those Vietnam veterans as well as of their families and societies. Accordingly, several Jungian veins can be seen throughout Rabe's Sticks and Bones.

Sticks and Bones is a two-act play that depicts a blinded veteran (David) who returns to his middle-class American family from Vietnam. They do not highly welcome his return. In addition, they eagerly help him to commit suicide.

In Sticks and Bones, Rabe recalls the Vietnam War which left its "inerasable imprints upon the American consciences in general" (Bigsby, A Critical Introduction, 324). Rabe considers this war as the main reason behind the prevalence of loss in the lives of the characters of the play. Besides, he tries to show its effects on the members of the American family and society. This is confirmed by Bigsby who considers Rabe as "a Vietnam playwright" (Contemporary American Playwrights, 85) and by Carla McDonough 
when stating that Rabe's works are "vivid microcosms of the time and society that they depict" (114).

Like the main character of his play and all the Americans who participated in the Vietnam War, Rabe feels a strong sense of negative reception when he is back again to his country. David Savran confirms this point saying:

$[\mathrm{H}] \mathrm{e}$ found himself at first in a society that seemed to have no interest in Vietnam. ('Everybody seemed removed totally from the war') and then in one in which the reality of the war disappeared in the issue of the war rather than its reality. ('People were interested in simplifications, in the debate about the war rather than in the experience of the war itself'). (In Their Own Words 193)

In addition to the impact of war upon Rabe's personal life, it creates within him the belief that it is a familial and a societal issue. Rabe's quoted words in the previous quotation illustrates that he notices two successive stages in the American society when coming back home. The first stage reflects the implicit sense of negative homecoming the veterans receive. The second stage concentrates more on the superficial issues rather than on actual realities.

Thus, Rabe's words can be understood as an invitation for a close reading of the Vietnam experience rather than the abstract theoretical statements about the issue of war involvement. This is confirmed by Rabe himself when stating in an interview with Philip Kolin that his plays are "about a kind of experience" ("An Interview" 154). In this interview, Rabe explicitly declared that he himself is the hero of Sticks and Bones rather than the blind veteran David. This is due to the fact that he is "the real core of the play" as "[h]e's the one on the journey. David comes into the play wild and angry; he is trying to compel Ozzie into action" ("An Interview" 155).

The dilemma of those who returned from the Vietnam War is that they have a twofold sense of loss. On the one side, they have a strong feeling of loss within themselves. On the other side of the picture, they are unable to communicate with the members of their families and socialize with the members of their societies. This sense of loss disables even the communicative function of the human language. Being "an authentic voice" of the Vietnam War, as Toby Zinman calls him, Rabe is an eyewitness of its brutal events of the war and their consequences ("Search and Destroy" 8). Through his dramatic and psychological lens, Rabe attempts to capture the scenes of this twofold loss. 
Before exposing the different scenes of the sense of loss, it is fruitful if one mentions the reasons behind this sense of loss. One of the main reasons behind the sense of loss within Rabe's dramatic characters is their inability to forget the scenes that they saw during the Vietnam war. The black memories of the war, which are stuck in their minds, fall into the kind of the inerasable type.

The best-example scene in Sticks and Bones that depicts this situation is that of delivering the dead bodies and the injured soldiers to their relatives. Such a situation seems to be repeated endlessly within the very depth of David's mind. He mistakenly imagines that all those surrounding him are in the same boat. This creates a gap, as chapter two shows, between the returned veteran and all other members of his family. His address to other members of his family recalls such meanings. He says:

Don't you hear the trucks? They're all over town, lined up from the center of the town to the country. Don't you hear? They've stopped bringing back the blind. They're bringing back the dead now. The convoy's broken up. There's no control...They're walking from house to house, through the shrubbery, under the trees, carrying one of the dead in a bright blue rubber bag for which they have no papers, no name or number. No one knows whose it is. (169)

Another important reason behind the sense of loss is attributed to the negative homecoming with which they are received when returning from the war, ironically enough, by their families. This negative homecoming plays an effective role in aborting any attempt to reintegrate those characters into their familial circle and into their societal context. This is best depicted in the negative homecoming of the blind David and in his inability to communicate with the members of his family.

On the individual level, David, after returning from the Vietnam War, faces an endless suffering. He returns home from the war physically blind. He wants to change the earlier world of his family. The result is that he seems to be at odds with himself. He is lost. He searches for his own identity.

David's personal suffering that widens his personal loss appears in different forms. The most important one is that of dehumanization. The most memorable inhuman scene in the play is that one of delivering David, the returned blind veteran, to his family. Such moments of delivery, which prove that the individual is no longer 
treated as a human being, are manifest in the following dialogue between Sergeant Major and Ozzie, David's father:

SERGEANT MAJOR (with a large sheet of paper waving in his hands): Who's gonna sign this for me, mister? It's a shipping receipt. I got to have somebody's signature to show you got him. I got to have somebody's name on the paper.

OZZIE: Let me. All right.

SERGEANT MAJOR: Just here and here, you see? Your name or mark three times. (As they moved toward a table and away from HARRIET, who is near DAVID). (103)

This dialogue depicts how veteran characters are dehumanized in a manner which makes them no more than packages whose delivery requires signatures.

In Contemporary American Playwrights, Bigsby calls the attention of his readers to an important aspect in the-above mentioned dialogue when he invites them to a close examination of Sergeant Major's tone:

SERGEANT MAJOR: I haven't time. I've got to get going. I've got trucks out there backed up for blocks. Other boys. I got to get on to Chicago and some of them to Denver and Cleveland, Reno, New Orleans, Boston, Trenton, Watts, Atlanta. And when I get back they'll be layin' all over the grass; layin' there in pieces all over the grass, their backs been broken, their brains jellied, their insides turned into garbage. No-legged boys and onelegged boys. I'm due in Harlem; I got to get to the Bronx and Queens, Cincinnati, St. Louis, Reading. I don't have time for coffee. I got deliveries to make across all this country. (104)

Reading the previous lines again, one agrees with Bigsby who observes that the tone of Sergeant Major's speech is more of "a delivery man" than of a Sergeant (266). Soldiers in this system are no more than scapegoats of war. They are specifically used for achieving victory over enemies. When this goal is lost, they become of no use. Being of no use, they are brought home in an extremely humiliating and debased way. No one can deny that such a dialogue should not leave a lifelong influence on David and should not deepen his feeling of loss. Besides, this a dialogue can generate within David a growing sense of resentment which extends not only to the members of his family or to his society at large, but also to everyone attempting to approach him even if it is a religious man like Father Donald himself.

In this context, one can recall the situation in which David's mother tells Father Donald that David is "troubled" (146). This is her simple 
diagnosis of David's case. Accordingly, she asked the priest to bless David in order to appease his anger and to cure him from such a psychological sickness. Yet, David's response to the visit of Father Donald is a strange one.

In an aggressive way, David says: "I don't want you here. Father; get out" (145), Whoever this person is, the result is the same. For this reason, one may assume that the failure to communicate with David remains the only conclusion reached in the play, simply because no one of this family notes that he is drastically changed.

The members of David's family still live in the past. They remember his past memories as a child and, consequently, they put him in such a narrow framework. They neither realize the fact that David is now a completely different person nor that he is no longer morally blinded like them although he is now physically blinded. Harriet, his mother, invites her family members to recall his funny situations in the beautiful past:

HARRIET: Oh, Ozzie, Ozzie, do you remember-I just remembered that time David locked himself in that old icebox. We didn't know where he was. We locked all over. We couldn't find him. And then there was this icebox in this clearing... out in the middle. I'll bet you don't even remember.

OZZIE: Of course I remember.

HARRIET: And he leaped to us. So frightened.

OZZIE: He couldn't even speak-he couldn't even speak-just these noises.

HARRIET: Or that time he fell from that tree.

OZZIE: My God, he was somethin'! ifhe wasn't failin', he was getting' hit.

HARRIET: And then, there was that day we went out into the woods. It was just all wind and clouds. We sailed a kite!

OZZIE: I'd nearly forgotten .... !

RICK [David's brother]: Where was I?

HARRIET: You were just a baby, Rick. We had a picnic. (99)

Here, the reader of this dialogue observes that the family fails to realize what is meant to be a Vietnam veteran. They are unable to imagine the indescribable experiences he gets from war. They fail to see the fact that if David cannot physically see them, he cannot fail to see these flaws dominating both his familial and social atmospheres. 
The members of David's family insist on turning a blind eye to him. They never listen to the him, nor give him a chance to speak. Even at the moment he speaks, none of them cares. Rather, they do believe that he constitutes "a threat to his family's well-being" (Cohn, 33). They neglect the influence of war upon him. This neglect enlarges the gap between them. Consequently, this deepens his sense of hatred towards anyone in his small family and all other members of hid society. This is simply because no one feels that he suffers. None of them notices that he is, in a word, lost.

On the familial and societal level, David's family serves as a microcosm of the American society as a whole. All the members of David's family, even the mother, vote for getting rid of their returned blind son. Instead of helping him via rehabilitating him, they help him to commit suicide.

The members of David's family never realize the new facts that dominate his life after the war experience. They still believe that the problem is only with David and they are successfully communicating with each other. They think that as long as they do the daily rituals of the American families, they are on the right track. They think that any one violates these rituals should be banished.

After coming back home, David, in their viewpoint, violates these images. He brings, as Gerald Berkowitz describes, "the sense of war, with its violence, cruelty, and instability, to their quiet home" (114). Furthermore, his beliefs are become different from theirs. This leads to his painful suffering. But, "David's suffering", as Janet Hertzbach expresses, "have not increased his capacity for tolerance and compassion; they have only enhanced his capacity to hate" (178).

So, Rabe, through David, casts light upon "the racial hatred that makes killing people of other colors and cultures easy, as well as the bland insensitivity of the American family to its children" (Zinman 12). This great distance between David and his family leads to the conclusion that "he is no longer a real member of the family, since he doesn't conform to tire family's ideology of what is real," as David McDonald summarizes (214).

For these reasons, David's family decides to terminate this dilemma by getting rid of David. They believe that his offensive acts waste their earlier state of happiness and stability. In doing so, they think, happiness returns again to their small home. Ozzie, after the goal is fulfilled, comments: "We're all happier" (175). This strongly proves that moral values are no longer there in the theatre of the family's 
mind. They depart from such an environment. They are lost in such an atmosphere in which all the members of the family, including THE MOTHER, Harriet, vote collectively for such a decision.

David and his family are involved in a strong clash. It is between what is firmly established, from the standpoint of David's family, as right and what is seen, from David's viewpoint, as the unquestionable truth. The only member of David's family that tends to pity him is his father. David's new attitudes drive him to reconsider his situation. This tendency drives Thomas Adlar to sum up in his expressive statement: "the son is the father of the man" (205). But the modification in David's father does not change the attitudes of the other members of the family. So, the two lines never meet. Moreover, there is not a chance that a state of reconciliation can put them together again in one track.

Rabe, in his introduction to The Basic Training of Pavlo Hummel \& Sticks and Bones, sheds light upon the opposition between the different viewpoints of the characters of Sticks and Bones. He says: "One of the major conflicts between the characters in Sticks and Bones is a disagreement about the nature of the world in which they are living, or, in other words, about the kind of language that is used to define experience" (XX).

The irresolvable opposition between David and his family is very clear in their collective attitude towards his Vietnamese beloved, Zung. For David, the imaginative presence of Zung does not only represent everything positive in his life, but it endows him with the sense that he is still alive. She stands for "total understanding," as David expresses (138). If the ability to communicate with his family, who are present in the same apartment, is disabled, it is not so with the ghostly presence of Zung. David speaking to her imaginative body:

I didn't know you were here. I didn't know. I'll buy you clothing. I've lived with them all my life. I'll make them not hate you. I'll buy you books. (And she is moving toward him now, coining down the stairs) they will see you. The seasons will amaze you. Texas is enormous. Ohio is sometimes green. There will be time. We will learn to speak. And it will be as it was in that moment when we looked in the dark and our eyes were tongues that could speak. (138)

If this is the way David sees Zung, his parents view her in a completely different way. They, as Bigsby expresses, regard her as "a threat to their notions of normality." This is because both Ozzie and Harriet consider "miscegenation" as "an affront" (Contemporary 
American Playwrights 266). Here, the different attitudes towards Zung show the extent to which the gap between David and his family is more broadened.

Furthermore, their different attitudes towards Zung refer to a social problem which is essentially derived from a moral loss. Thomas Adler, in Mirrors on the Stage, discusses how Sticks and Bones evokes a major moralistic problem in the American society, notably, the issue of "racial discrimination" (55). It proves how the moral values, calling for equating human beings with one another, are no longer observed. For these different reasons, David's family sees that the only way out of this dilemma is to silence him forever. Thus, David becomes the scapegoat of his family's wrong attitudes, and, at the same time, the scapegoat of the American society at large.

To sum up, what makes the audience feel pity towards David is that he is treated inhumanly at the hands of both his family and his society alike for reasons beyond his sphere. Again, he is delivered to his family as a package. Thus, his humanity is, again, devalued. The final result is that he loses confidence not only in himself as a human being, but also in the society that imposes such a sense of dehumanization upon his way of life as a whole.

In conclusion, Sticks and Bones is a play that is stuffed with dramatic scenes and situations through which one draws the conclusion that the characters' struggle deepens their sense of loss in its individual, familial and societal levels. Thus, in this play, Rabe successfully captures the lost individual whose attempts to decode the complex codes of his/her enigma end in failure. The failure of locating a definite meaning for the individual's life extends to invade the familial and social lives as well. 


\section{Works Cited}

Abrams, M. H. A Glossary of Literary Terms. 7thed. Australia: Heinle \& Heinle, 1999.

Adams, Michael Vannoy. "The Archetypal School." The Cambridge Companion to Jung. Eds. Young-Eisendrath, Polly and Terence Dawson. Cambridge: Cambridge UP, 2008. 107-24

Adler, Thomas P. "The Blind Leading the Blind: Rabe's Sticks and Bones and Shakespeare's King Lear." Papers on Language \& Literature, 15, (1979): 203-206. JSTOR. 5 Sept. 2010.

. Mirror on the Stage: The Pulitzer Plays As an Approach to American Drama. West Lafayette, Indiana: Purdue UP, 1987.

Berkowitz, Gerald M. American Drama of the Twentieth Century. New York: Longman, 1992.

Bigsby, Christopher W. E. Contemporary American Playwrights. Cambridge: Cambridge UP, 1985.

-------. A Critical Introduction to Twentieth-Century American Drama. New York: Cambridge UP, 1985.

Cohn, Ruby. New American Dramatists 1960-1990. London: Macmillan, 1991.

Hertzbach, Janet S. "The Plays of David Rabe: A World of Streamers." Essays on Contemporary American Drama. Eds.Hedwig Bock and Albert Werrbeim. Munich: Heuber, 1981, 173-186.

Jung, C. G. Psychological Types. Trans. FI. G. Baynes. London: Routledge, 1971.

Kolin, Philip. "An Interview with David Rabe.” Journal of Dramatic Theory and Criticism. 3 (1989): 135-56.

McDonough, Carla. Staging Masculinity: Male Identity in Contemporary American Drama. Jefferson: McFarland, 1997.

McDonald, David. "The Mystification of Vietnam: David Rabe's Sticks and Bones." Cultural Critique 3 (1986): 211-34. JSTOR. 4 Nov. 2010. 
Rabe, David. The Basic Training of Pavlo Hummel \& Sticks and Bones. New York: Grove Press, 1993.

Savran, David. In Their Own Words: Contemporary American Playwrights. New York: Theatre Communications Group, 1988.

Zinman, Toby Silverman, ed. David Rabe: A Casebook. New York: Garland Publishing, Inc. 1991.

---. "Search and Destroy: The Drama of the Vietnam War." Theatre Journal. 43 (1990): 5-26. JSTOR. 4 Nov. 2010. 